\title{
Effect of soil edaphic factors on Rhizoctonia solani mediated diseases in major vegetable brassica growing districts of West Bengal
}

\author{
LICON KUMAR ACHARYA
}

Department of Plant Pathology, Bidhan Chandra Krishi Viswavidyalaya, Mohanpur, NADIA(W.B.) INDIA

\section{ARITCLE INFO}

Received : 23.02 .2017

Revised : 21.03 .2017

Accepted : 25.03.2017

\section{KEY WORDS :}

Vegetable brassica, Rhizoctonia solani, Wire stem, Soil $\mathrm{pH}$, Available carbon

Email : likuamir24@gmail.com

\begin{abstract}
Gangetic alluvial region is the most fertile part of West Bengal where majority of farmers' livelihood is commercial vegetable production. Vegetable brassica such as cabbage, cauliflower and radish occupies 18 per cent of total vegetable cultivation in West Bengal and mainly cultivated in Nadia, Mursidabad, Purulia, North 24 praganas and South 24 praganas districts.Damping off, wire stem and root rot are the major diseases caused by Rhizoctonia solani in these districts. Different soil edaphic factors like soil temperature, soil $\mathrm{pH}$, available carbon, available nitrogen etc. play a major role in survival and spread of Rhizoctonia solani and hence, this study was undertaken. The survey reveals that among different soil edaphic properties; soil $\mathrm{pH}$, organic $\mathrm{C}$ and available $\mathrm{N}$ $(\mathrm{kg} / \mathrm{ha})$ are the important determinants of disease conduciveness and suppressiveness. Soil $\mathrm{pH}$ is the most important determining factor for disease development. The disease incidence is negatively correlated with the $\mathrm{pH}$.
\end{abstract}

How to view point the article : Acharya, Licon Kumar (2017). Effect of soil edaphic factors on Rhizoctonia solani mediated diseases in major vegetable brassica growing districts of West Bengal. Internat. J. Plant Protec., 10(1) : 146-150, DOI : 10.15740/HAS/IJPP/10.1/146-150. 